\title{
PENYIMPANGAN BAHASA DALAM SEBUAH PUISI
}

\author{
Dra Henilia, M.Hum \\ Universitas Amir Hamzah \\ henilia87@yahoo.co.id
}

\begin{abstract}
Abstrak
Puisi memiliki bahasa yang berbeda dengan karya prosa. Struktur yang padat dan penuh kontemplasi membuat penyair menggunakan berbagai penyimpangan bahasa. Penyimpangan bahasa terdiri dari penyimpangan leksikal, semantis, fonologis, morfologis, sintaksis, dialek, register, historis, dan grafologis. Puisi sebagai salah sebuah karya seni dapat dikaji dari bermacam-macam aspeknya. Puisi merupakan salah satu karya yang dapat dikaji dari bermacam-macam aspek. Puisi dapat dikaji dari struktur dan unsurunsurnya, mengingat bahwa puisi merupakan struktur yang tersusun dari bermacam unsur atau ragam. Puisi juga dapat dikaji dari sudut kesejarahannya, mengingat sepanjang sejarahnya, dari waktu ke waktu puisi selalu mengalami perubahan dan perkembangan. Puisi termasuk salah satu jenis sastra yang digemari masyarakat. Karena kemajuan masyarakat dari waktu ke waktu terus meningkat, maka corak, sifat dan bentuk puisi pun berubah, mengikuti perkembangan jaman.
\end{abstract}

Keyword : Penyimpangan Bahasa, Puisi. 


\section{PENDAHULUAN}

Puisi sebagai karya seni yang puitis. Kata-kata puitis sudah mengandung nilai keindahan yang khusus untuk puisi. Sifat yang disebut puitis, sukar didefinisikan. Hanya saja, dalam karya sastra sesuatu dikatakan puitis apabila membangkitkan perasaan, menarik perhatian, menimbulkan tanggapan yang jelas. Secara umum, bila menimbulkan keharuan disebut puitis (Pradopo, 2009:13).

Tetapi masih banyak di dalam masyarakat tidak mengetahui bahwasanya terdapat kesalahan penggunaan bahasa dalam puisi serta tidak mengetahui kedudukan bahasa yang digunakan dalam bahasa tersebut. Oleh karena itu seharusnya apabila kita menulis sebuiah puisi, maka wajib memperhatikan gaya bahasa termasuk unsur-unsur didalamnya. Banyak cara dilakukan orang untuk menyampaikan perasaannya. Salah satunya melalui puisi. Puisi juga dapat digunakan sebagai media untuk menyampaikan kritikan. Melalui puisi kritikan disampaikan secara tidak langsung sehingga dibutuhkan pengetahuan tentang pemahaman makna dan rasa kesensitifan dalam berbahasa (rasa bahasa). Untuk mendapatkan "isi" sebuah puisi, diperlukan pengetahuan tentang aspek-aspek kebahasaan, di antaranya adalah aspek semantik atau ilmu bahasa yang membahas tentang makna. Benveniste melalui Semiotik dan Penerapannya dalam Karya Sastra mengungkapkan bahwa pengertian tentang semantik membawa kita ke ranah penggunaan bahasa. Bahasa berfungsi sebagai penghubung antara manusia dan manusia lain, antara manusia dan dunia, antara jiwa dan benda-benda, penyampai informasi, dan pengomunikasi pengalaman.

Bahasa yang digunakan dalam puisi merupakan bahasa yang kompleks. Kata yang diambil biasanya singkat karena dibatasi oleh rima atau bait. Namun, kata tersebut harus dapat memberikan makna yang luas seperti yang diharapkan oleh pengarang dan juga mengandung unsur keindahan. Hal itulah yang menyebabkan mengapa bahasa dalam puisi meskipun bersifat denotatif, makna yang terkandung dapat bersifat konotatif. Teks puitik tidaklah tersusun dari kata-kata yang khusus. Katakata yang jarang digunakan juga belum tentu membawa makna puitis yang istimewa. Seringkali justru kata-kata biasa dengan penggunaannya yang baru yang 
menciptakan kesan puitik. Aspek semantik dapat diterapkan dalam memahami puisi. Salah satu di antaranya dengan menganalisis kosakatanya, yaitu pilihan kata dan konotasi yang ditimbulkannya. Kata hijau, misalnya, memunyai konotasi segar, riang, muda, polos, dan sebagainya. Kata malam memunyai konotasi kegelapan, ketakutan, keheningan, dan sebagainya. Konotasi yang dipilih sangat bergantung pada konteks dan memang landasan makna yang utama bagi puisi adalah konotasi. Puisi sangat kental dengan imaji atau daya khayal pengarangnya. Imaji verbal adalah suatu fenomena. Melalui fenomena ini kata-kata yang mengacu pada realita yang berbeda berhubungan dalam frasa yang sama. Dari segi teknik, munculnya imaji ini juga disebabkan oleh adanya gaya bahasa, terutama metafora Schmitt dan Viala dalam Savoir-lire berpendapat bahwa kesan yang ditimbulkan oleh seseorang dalam memahami sebuah puisi sangat bervariasi. Apabila asosiasi kata-kata telah umum digunakan dan telah menjadi biasa, yang digunakan adalah konotasi konvensional. Namun, hal itu hanya menjadi ungkapan klise atau stereotip. Biasanya, kata "klise" ini memunyai makna yang kurang berbobot karena kata itu terlalu sering digunakan dan telah menjadi biasa serta mengacu pada imaji yang "tetap". Memang masih banyak lagi unsur yang membangkitkan makna konotasi pada puisi. Namun, sebagaimana dikemukakan di atas, landasan makna yang utama bagi puisi adalah konotasi.

\section{KAJIAN PUSTAKA}

Penyimpangan bahasa puisi merupakan gejala linguistik yang khas di dalam puisi namun tidak sesuai dengan sistem atau norma kebahasaan. Di dalam puisi banyak faktor yang menjadi penyebab terjadinya penyimpangan bahasa, paling tidak dapat dirinci sebagai berikut:

1. Penyimpangan bahasa pada penulisan kata dilakukan untuk mencapai efek estetis, baik untuk permainan bunyi, rima, dan irama, maupun untuk enjabemen dan tipografi. 
2. Penyimpangan bahasa pada penggunaan dialek terjadi karena bahasa resmi tidak mampu merepresentasikan konsep yang terdapat di dalam dialek.

3. Penyimpangan bahasa pada penggambaran wujud puisi dilakukan karena bentuk konvensional tidak mewakili makna yang akan disampaikan di dalam puisi.

Faktor-faktor tersebut akan terus terjadi selama bentuk konvensional tidak sesuai dengan apa yang diinginkan oleh para penyair. Dalam contoh-contoh di bawah ini akan terlihat bagaimana penyair melakukan penyimpangan-penyimpangan tersebut di dalam puisinya. Penyimpangan-penyimpangan tersebut meliputi penyimpangan leksikal, penyimpangan semantis, penyimpangan fonologis, penyimpangan morfologis, Penyimpangan sintaksis, penyimpangan dialek, penyimpangan register, penyimpangan historis, dan penyimpangan grafologis.

\section{Penyimpangan Leksikal}

Penyimpangan leksikal adalah penyimpangan yang terjadi pada tataran penulisan kata yang tidak sesuai dengan kaidah bahasa. Penyimpangan tersebut bukan terjadi akibat salah ketik, namun dimaksudkan oleh penyair untuk maksud tertentu. Dalam puisi D. Zawawi Imron, ia menulis kata ilalang menjadi lalang.

\section{Penyimpangan Semantis}

Penyimpangan semantis adalah penyimpangan yang terjadi pada tataran makna sebuah kata. Makna kata yang semula bernilai rasa biasa kemudian berubah sehingga memiliki makna yang luar biasa. Kemunculan kata tersebut bergantung kepada latar belakang penyairnya. Misalkan kata tembakau dan garam menjadi makna yang berbeda di hadapan para penyair Madura pada umumnya. Tembakau dan garam tidak lagi hanya menjadi bahan untuk membuat rokok dan bumbu dapur, namun tembakau dan garam telah bermakna napas hidup, ritual 
keagamaan, dongeng masa kanak, warisan budaya, dan makna lainnya. Perhatikan dua penyair Madura menulis garam dalam sebuah puisi.

\section{Penyimpangan Fonologis}

Penyimpangan fonologis adalah penyimpangan yang terjadi pada bentuk bunyi. Bunyi yang terdapat di dalam puisi tersebut tidak sesuai dengan bentuk bunyi yang sesuai kaidah. Penyimpangan fonologis sejalan dengan morfologis, karena pembunyian di dalam puisi sifatnya tertulis. Dalam puisi Lagu Ibu karya WS Rendra kata merica ditulis mrica. Dalam puisi ini Rendra seakan ingin menghilangkan bunyi vakal e pada kata tersebut.

\section{Penyimpangan Morfologis}

Penyimpangan morfologis adalah penyimpangan yang terletak pada cara pembentukan kata. Pembentukan kata tersebut tidak sesuai dengan kaidah bahasa. Ketidak sesuaian tersebut dilakukan antara lain karena ingin membangun suasana dan bunyi di dalam puisi. Misal saja dalam puisi Mahwi Air Tawar di atas dalam puisi Tanah Garam. Kata tanah ditulis dengan tana seperti tampak pada baris Antara tana merah, retakan kemarau dan Di sepetak tana impian. Frasa tana merah dan tana impian seakan memberikan petunjuk kepada pembaca dengan kultur budaya madura. Tanah sering disingkat menjadi $n a$, sehingga tanah merah sering dibunyikan namirah.

\section{Penyimpangan Sintaksis}

Penyimpangan sintaksis adalah penyimpangan terdapat pada tataran pembentukan sebuah kalimat. Susunan kalimat dalam kaidah bahasa Indonesia paling tidak tersusun minimal terdiri dari Subjek dan Predikat. Dalam puisi Sutardji Calzoum Bachri berjudul Luka, tidak terlihat ada subjek dan predikatnya. 


\section{Penyimpangan Dialek}

Penyimpangan dialek adalah penyimpangan yang terletak pada penggunaan dialek dibandingkan dengan bahasa resmi. Penggunaan dialek tersebut dipilih karena bahasa daerah dianggap lebih mewakili gagasan atau konsepnya dibandingkan bahasa resmi. Indonesia memiliki ragam dialek yang banyak. Tentu keragaman tersebut membuat puisi di Indonesia sangat kaya. Beberapa penulis sengaja memberikan dialek untuk menuangkan gagasan estetiknya.

\section{Penyimpangan Register}

Penyimpangan register adalah penyimpangan yang terletak pada penggunaan bahasa atau istilah yang hanya dipahami oleh sebuah kelompok atau profesi tertentu dalam masyarakat. Kata-kata di dalam penyimpangan register ini merupakan kata-kata yang umumnya digunakan dalam ragam bahasa berdasarkan topik pembicaraan. Misalnya, kata lingua franca dalam topik linguistik, istilah tersebut jika dicari tidak ada di dalam KBBI, namun terdapat di dalam kamus leksikon linguistik. Akan tetapi, tidak semua penyimpangan register baru ditemukan di leksikon khusus, kadang pula suda masuk kamus umum namun istilah tersebut tetap tidak dimengerti oleh masyarakat pada umumnya. Dalam puisi Tanggamus, Wayan Sunarta menggunakan istilah-istilah arkeologi, yaitu nama-nama batu, antara lain, dolmen, monolit, menhir pada bait ketiga dalam puisi tersebut. Ketiga istilah ini akan asing di mata para pembaca apalagi yang tidak mencintai dunia arkeologi.

\section{Penyimpangan Historis}

Penyimpangan historis merupakan penyimpangan yang terletak pada penggunaan kata-kata yang sudah jarang digunakan atau arkeis di dalam sebuah puisi. Penggunaan kata-kata arkeis atau yang jarang digunakan masyarakat tentu menjadi sebuah penyimpangan lantaran ekspresi kebahasaan sebaiknya menggunakan kata yang dipahami, pemahaman akan muncul jika kata-kata tersebut sering digunakan. Dalam puisi Abimardha Kurniawan berjudul Nelayan Pesisir ia menggunakan kata sakal sebagai ganti angin. Kata ini sudah jarang digunakan oleh masyarakat pada umumnya. Berikut kutipan puisinya, 
Penggunaan kata sakal dalam puisi tersebut agaknya digunakan penyair untuk membentuk rima tertentu. Hal ini terlihat pada baris ketiga bait tersebut, kata nakal memberi peran rima untuk kata sakal.

\section{Penyimpangan Grafologis}

Penyimpangan grafologis adalah penyimpangan yang terletak pada bentuk penulisan kata, kalimat, larik, dan baris yang tak sesuai dengan kaidah bahasa. Penyimpangan grafologis memiliki peran tersendiri di dalam puisi. Dapat sebagai pelengkap suatu makna, namun juga dapat dijadikan sebagai hiasan di dalam puisi. Dalam puisi-puisi Sutardji Calzoum Bachri terlihat gejala tersebut, misalnya pada puisi $Q$, Ah, Pot, Tragedi Winka dan Sihka, batu, dan puisi lainnya. Puisi di atas secara tipografi masih terpola dengan jelas, berbeda dengan puisi Q, Pot, dan Ah yang sepertinya tidak memiliki pola yang jelas dalam pembaitannya. Meskipun demikian, pola di atas sangat tidak konvensional sehingga termasuk ke dalam penyimpangan grafologis.

\section{METODE PENELITIAN}

Jenis penelitian yang digunakan yaitu penelitian kualitatif. Metode kualitatif sebagai prosedur penelitian yang menghasilkan data deskriptif berupa kata-kata tertulis atau lisan dari orang-orang atau perilaku yang dapat diamati. (Maloeng, 2012). Metode kualitatif ini peneliti pakai agar bisa menyesuaikan kondisi disaat berhadapan dengan kenyataan ganda. Metode ini juga memberikan hakikat yang terkait antara peneliti dan responden secara langsung dikarenakan metode ini lebih membuat peneliti untuk menyesuaikan diri terhadap pola-pola nilai yang dihadapi peneliti. (Ahmad Tanzeh dan Suyitno, 2006)

Pendekatan penelitian yang dipakai pada penelitian ini yaitu deskriptif. Jenis penelitian deskriptif merupakan penelitian yang berusaha memberikan gambaran secara sistematis dan cermat terhadap fakta-fakta aktual serta sifat-sifat dari suatu populasi tertentu. (Zuriah, 2009). Penelitian ini berusaha memaparkan suatu gejala ataupun keadaan secara sistematis sehingga subjek penelitian menjadi 
lebih jelas. Adapun tujuan dari penelitian ini yaitu menganalisis penyimpangan bahasa dalam puisi. Sesuai dengan tujuan penelitian nya pendekatan ini mengungkap fakta baik lisan maupun tulisan dari berbagai sumber data yang didapatkan dari partisipan yang selanjutnya diuraikan dengan jelas dan ringkas.

\section{PEMBAHASAN}

Puisi: Kidung Rindu Bagi Perempuanku

Kidung Rindu Bagi Perempuanku

Dalam tubuh malam, aku berlayar Lautnya

berombak rembulan keteduhan Di atas biduk,

kudendangkan lagu kerinduan

Duhai, perempuanku, telah berjamjam kau berlalu

Membagi kesepian yang dada bertalu

Bila matahari telah singsing, di esok senja yang dingin

Aku telah menemuimu dengan dekap dan peluk

Begitu katamu, pada suatu pagi yang teramat asing

Demikianlah, malam ini aku mengakrabi kesunyian

Di antara deru jalanan yang gaduh, angin yang gemuruh

Sisa-sisa hujan tadi sore yang membikin tanah basah-resah

Dan betapa sungguh secangkir kopi yang kuseruput

Menjadi tawar, menjadi hambar, disesaki ingatan pekat

Dan bau tubuhmu yang senantiasa terus melekat

Dalam tubuh malam, aku terus berlayar

Lautnya berombak rembulan keteduhan

Di atas biduk, kudendangkan lagu kesepian

Duhai, perempuanku, dari sekian banyak ketakutanku

Yakinlah kalau aku tak mampu melupakanmu

Jember, 06 Oktober 2012

Puisi Alif di atas melakukan tiga penyimpangan bahasa yakni penyimpangan sintaksis, penyimpangan historis, dan penyimpangan morfologis. Penyimpangan sintaksis secara keseluruhan terlihat pada tidak 
adanya tanda titik dalam puisi berjudul Kidung Rindu Bagi Perempuanku. Meski pada bait keempat Alif melakukan kembali penyimpangan sintaksis dengan meletakkan kata dan pada awal baris puisi. Jika dilihat bentuknya yang ditulis kapital, maka bisa ditafsirkan bahwa setiap baris adalah awal kalimat, maka dan pada puisi tersebut telah melakukan penyimpangan sintaksis.

Adapun penyimpangan historis terlihat pada bait kedua dalam puisi ini, Alif menggunakan kata duhai yang kini tidak lazim digunakan. Sehingga dapat dikatakan apa yang dilakukan Alif ini adalah penyimpangan historis. Untuk penyimpangan leksikal terlihat pada bait kedua pula, bagaimana pengulangan kata tidak ditulis sebagaimana mestinya, yakni berjamjam. Tidak adanya tanda pemisah ketika melakukan pengulangan kata, menjadi tanda bahwa puisi ini telah melakukan penyimpangan leksikal.

\section{Puisi: Aek Sarulla}

Aek Sarulla Sahabat,

kuingin sajikan pelipur lara

Membasuh ratap dan luka hati,

Karna di depan waktu terentang

Dan hentakan perjalanan masih panjang.

Sahabat, lupa tak bisa, otak terus berjaga, Asal hiburanmu tak menambah nestapa.

Untukmu lagu harapan,

Penyejuk hati penyegar pikiran:

"Aek Sarulla,

Aek Sarulla kemana kau pergi?

Jalanmu panjang nian, sudi bisikkan padaku

Yang kau lihat dan alami sepanjang hari.

Kuharap beritamu menyenangkan hati".

Wah sejuk, sejuk nian itu madah.

Kutahu Aek Sarulla,

Kecil, mungil lagi cantik. 
Beritanya ke pelosok dunia,

Rindu memandangnya sejak lahirnya,

Karena bisikannya hanya damai

Seperti aku, nenek dari neneknya.

Oh cicit dari cicitku,

Air nan indah dan damai

Semoga ceritamu selalu indah seperti namamu.

Puisi karya Mangasi ini melakukan dua penyimpangan bahasa. Penyimpangan tersebut terdiri dari penyimpangan dialek dan historis. Penyimpangan bahasa pertama adalah penyimpangan dialek. Pada puisi ini dialek terlihat menjadi jantung inspirasi bagi karya Mangasi ini. Hal ini terlihat bagaimana kata Aek Sarulla menjadi judul puisi ini. Aek Sarulla merupakan lagu rakyat Batak yang berarti Sungai Sarulla.

Penyimpangan yang kedua ialah penyimpangan historis. Penyimpangan ini terlihat pada tiga kata yang digunakan. Masing-masing terdapat pada bait keempat dan kelima. Pada bait keempat di baris pertama terdapat dua kata nian dan madah yang akan bahasa yang sudah jarang digunakan. Sementara dibait kelima terlihat pada baris keempat kata nanyzng juga sudah jarang digunakan. Oleh karena itu, puisi karya Mangasi ini dapat disebut melakukan penyimpangan historis.

\section{Puisi: Di Jembatan Pasupati Di Jembatan Pasupati}

jika di sini aku berbagi kopi dengan plato aku tak lagi amini pengemudi rusuh selalu banyak musuh tapi di jembatan layang yang membelah makam-makam karuhun dan angina pasundan ini aku hanya sendiri mencari- cari arah datang waktu 
Dalam puisi karya Fajar ini terdapat empat penyimpangan bahasa. PenyimpanganBahasa tersebut terdiri dari penyimpangan sintaksis, penyimpangan grafologis, penyimpangan register, dan penyimpangan dialek. Penyimpangan sintaksis yang dilakukan Fajar dalam puisinya ini terlihat tidak adanya tanda baca dalam puisi ini. Baik koma, tanda titik, atau bahkan tanda seru dan tanya. Selain itu, jika merujuk pada enjabemen dalam ketiga bait puisi Fajar ini terasa kurang tepat, misalnya dibait pertama pemenggalan itu dilakukan dengan asal: aku berbagi kopi/ dengan plato, padahal ada kemungkinan baginya untuk menuliskannya dalam satu baris. Hal ini dirasa kurang tepat lantaran membuyarkan struktur sintaksis bahasa. Oleh karena itu, dapat disebut pula apa yang dilakukan Fajar ini sebagai penyimpangan sintaksis.

Untuk penyimpangan grafologis terlihat pada bagaimana bentuk puisi ini melakukan enjabemen dengan seenaknya. Fajar tidak memperhatikan pemenggalan bait yang baik atau bahkan memang melakukan hal tersebut untuk menyiratkan pesan secara kuat. Oleh karena itu, usaha yang dilakukan Fajar ini dapat disebut sebagai penyimpangan grafologois.

Selain dua penyimpangan tersebut, Fajar melakukan penyimpangan register.

Penyimpangan ini terlihat pada baris puisi aku tak lagi amini. Kata amini dalam puisi tersebut menyiratkan kelas sosial tertentu yakni bahasa agamawan. Hal ini karena kata amin, merupakan sesuatu yang lazim disampaikan dalam suatu ritual ibadah.

Penyimpangan lain yang dilakukan Fajar adalah penyimpangan dialek. Penyimpangan ini terlihat pada bait kedua baris keempat, kata karuhun digunakan Fajar untuk menyampaikan maksud puisinya yang barangkali tak dapat disampaikan kecuali dengan menggunakan bahasa dialeknya. 


\section{KESIMPULAN}

Penyimpangan bahasa puisi merupakan pola penulisan yang khas di dalam puisi yang berbeda dengan struktur atau kaidah bahasa resmi. Penyimpangan bahasa puisi terbagi menjadi sembilan, yaitu: penyimpangan leksikal, penyimpangan semantis, penyimpangan fonologis, penyimpangan morfologis, penyimpangan sintaksis, penyimpangan dialek, penyimpangan register, penyimpangan historis, dan penyimpangan grafologis.

Dari pembahasan tersebut, dapat disimpulkan bahwa gaya bahasa terhadap suatu karya sastra khususnya puisi sangatlah penting. Karena dengan adanya gaya bahasa maka puisi tersebut bervariatif dan bagus. Didalam unsur puisi terdapat beberapa gaya bahasa yaitu gaya bahasa berdasarkan nada, gaya bahasa berdasarkan pilihan kata, gaya bahasa berdasarkan struktur kalimat, dan gaya bahasa berdasarkan langsung tidaknya makna. Selain itu majas juga terdapat dalam gaya bahasa yang biasanya sering digunakan pada saat membuat puisi. Karena dengan majas pilihan kata dalam puisi menjadi lebih bervariatif, selain itu majas dapat membuat penekanan-penekanan terhadap isi suatu puisi. Sehingga puisi tersebut lebih berbobot dan pembaca lebih bisa memahami serta mengikuti apa yang ditulis penyair. Gaya bahasa yang terkandung dalam suatu karya akan membuat karya akan menjadi lebih bagus. Pilihan kata dan majas akan membuat karakteristik dan keistimewaan puisi itu sendiri. Karena gaya bahasa suatu karya sastra puisi itu muncul dengan seiring berjalannya imajinasi si penulis. Oleh karena itu seharusnya apabila kita menulis sebuiah puisi, maka wajib memperhatikan gaya bahasa termasuk unsur-unsur didalamnya.

\section{REFERENCES}

Leech, Geoffrey N. 2000. A Linguistic Guide to English Poetry. New York: Longman.

Maloeng, L. J. (2012). Metodologi Penelitian Kualitatif. Bandung: PT. Remaja Rosdakarya. 
Solihati, Nani, Ade Hikmat, dan Syarif Hidayatullah. 2016. Teori Sastra: Pengantar Kesusastraan Indonesia. Jakarta: Uhamka Press.

Tanzeh. Ahmad dan Suyitno. (2006). Dasar-Dasar Penelitian. Surabaya: eLKAF. Zuriah, N. (2009). Metodologi Penelitian Sosial dan Pendidikan. Jakarta: PT. Bumi Aksara. 